Original Article

Received/Accepted

Dates

09.10.2021/06.11.2021

DOI

10.52096/usbd.5.23.5.16
International Journal of Social Sciences

Uluslararası Sosyal Bilimler Dergisi

Www.sobider.net ISSN: 2548-0685

\title{
Seçimlerin Ekonomik Etkileri: Türkiye Üzerine Bir Uygulama
}

\author{
Prof. Dr. Funda YURDAKUL \\ Ankara HBVÜ İ̈BF Ekonometri Bölümü \\ funda.yurdakul@hbv.edu.tr \\ Orcid No: 0000-0003-3999-4201
}

Özet

Arda DOĞRUÖZ

Yalova Üniversitesi, İİB İktisat Bölümü arda.dogruoz@yalova.edu.tr

Orcid No: 0000-0002-3910-0186

Bu çalışmada, seçim dönemlerinin ekonomi üzerindeki etkileri "kamu tercihi teorisi" kapsamında ele alınmak istenmiştir. Seçimlerin, politik iş çevrimleri kapsamında ele alınan çalışmaların odaklandığı değişkenlerden ihracat, Gayrisafi Yurtiçi Hasıla (GSYH), Toptan Eşya Fiyat Endeksi (TEFE), işsiz sayısı, takipteki krediler değişkenleri seçilmiş ve bu değişkenlerin içsel değişsen olarak ele alındığ 1 eşanlı modeller kurulmuştur. Bu modellerde genel ve yerel seçimler için kukla değişkenler kullanılmış ve araştırma dönemi 2002:04-2020:04 olarak belirlenmiştir. Kurulan ekonometrik modellerin katsayıları Engle-Granger ve Dinamik En Küçük Kareler yöntemleri ile tahmin edilmiştir. Analiz sonuçları seçimlerden önce alınan manipülatif kararların ve ayarlamaların her zaman iş çevrimi yaratmayacağını göstermektedir. Seçim dönemlerinde yapılan harcamalar sistemde kalıcı bir yük haline gelir ve seçim dönemlerindeki ekonomik ayarlamalar politik iş çevrimleri yaratmayabilir. Ayrıca iktidarın politika amaçlarını manipüle etmeleri, politika araçlarını manipüle etmelerine göre daha zordur. Çünkü kamu harcamaları, para arzı gibi politika araçları büyük oranda iktidarın kontrol alanında iken Gayri Safi Yurtiçi Hasıla, ihracat, enflasyon ve işsizlik gibi göstergelere iktidar müdahalesi daha sınırlıdır.

Anahtar Kelimeler:Engle-Granger Yöntemi, Dinamik En Küçük Kareler Yöntemi, Politik İş Çevrimleri.

Jel Kodu: E32, C01, G18 


\title{
Economic Effects of Elections: A Case Study For Turkey
}

\begin{abstract}
This study aims to explore the effects of election periods on the economy from the perspective of the "public choice theory". We selected our variables from among those focused by the research that examine elections from the standpoint of political business cycles; i.e., exports, Gross Domestic Product (GDP), Wholesale Price Index(TEFE), the number of unemployed, and nonperforming loans. Then, we constructed simultaneous models in which these variables were explored as endogenous variables. We used dummy variables for general and local elections in these models and identified 2002:04-2020:04 as our study period. We estimated the coefficients for the econometric models we constructed by using the Engle-Granger and Dynamic Least Squares methods. Our analysis results demonstrate that manipulative decisions and arrangements made before elections do not always create business cycles. Expenditures during election periods impose a permanent burden on the system and the economic arrangements during election periods may not result in political business cycles. Moreover, it is harder for the government in power to manipulate policy objectives than to manipulate policy instruments. Because policy instruments such as public expenditure and money supply are largely controlled by the government in power, while government intervention in indicators such as Gross National Product, exports, inflation, and unemployment is relatively limited.
\end{abstract}

Keywords: Engle-Granger Method, Dynamic Least Squares method, Political Business Cycles. Jel Code: E32, C01, G18

\section{Giriş}

Seçimler, halkın egemenliğini ortaya koymak adına periyodik olarak yapılan ve oy verme yeterliliklerine sahip olan halk tarafından kanunlarca belirlenmiş adaylar arasından seçim yapma işlemidir. Siyasi sürecin en önemli parçalarından biri olan seçimlerin, sosyal ve ekonomik anlamda yadsınamayacak etkileri bulunmaktadır. Bu etkileri incelemek için disiplinler arası bir yaklaşım 
gerekebilmektedir. Kamu tercihi teorisi bu noktada seçimlerin etkilerini incelemek için geliştirdiği araç ve yöntemler ile gerekli teorik altyapıyı sağlamaktadır.

Kamu tercihi teorisi kapsamında ele alınan politik iş çevrimleri, seçim dönemlerinin etkileri üzerine yoğunlaşmakta ve ekonomide meydana gelen iş çevrimlerini ifade etmektedir. İktidar sahibi politikacıların, ellerinde bulunan yönetme gücü ve geniş yetkiler aracıllğıyla seçimler öncesinde birtakım siyasi sebepli ayarlamalar yapabileceği ve bundan dolayı ekonomide dalgalanmalar doğurabileceği varsayımı politik iş çevrimlerinin temelinde yatmaktadır. Genellikle belirli aralıklarla tekrar eden seçimler ve seçimlerden kaynaklanan bu iş çevrimlerinin önemli sonuçları olabilir.

Politika yapıcılar, iktidarını koruma güdüsüyle seçim gününe dek kamu harcamalarını ve para arzını arttırarak genişletici politikalar uygulayabilir. Bu politikaların kısa vadede yaratacağı işsizlik, faiz oranlarının azalması ve enflasyonun artması gibi sonuçlar karşısında iktidar bu kez, seçim sonrasında daraltıcı politikalar ile enflasyonu düşürmeye odaklanarak iş çevrimleri yaratabilirler (Ekelund ve Tollison, 1986:734). Seçim dönemlerinde ekonomi üzerinde bu tür siyasi iktidar tarafindan meydana gelen ayarlamaların varlığı ve eğer varsa bunun sonuçlarının araştırılması kamu tercihi teorisi kapsamında dikkat çekici bir husus olarak kabul edilmektedir.

Seçimlerin, politik iş çevrimleri kapsamında ele alındığı birçok bilimsel çalışma vardır. $\mathrm{Bu}$ çalışmaların odaklandığı değişkenler de genellikle ekonomik büyüme, enflasyon, işsizlik oranı, para arzı ve kamu harcamaları olarak dikkat çekmektedir. Bu çalışmanın amacı da kamu tercihi teorisi kapsamında ele alınan politik iş çevrimlerinin Türkiye'deki seçimlerde etkili olup olmadığına dair bulguları, gerçekleştirilen son seçimleri kapsayacak biçimde ortaya koymaktır. Seçimleri, politik iş çevrimleri kapsamında incelemek için ihracat, Gayrisafi Yurtiçi Hasıla, Toptan Eşya Fiyat Endeksi, işsiz sayısı, takipteki kredilerin içsel değişkenler olarak alındığı 5 ayrı eşanlı modeller kurulmuştur. Bu doğrultuda seçilen değişkenler, 2002:04-2020:04 dönemlerini kapsayan çeyreklik verilerden oluşmaktadır. Ekonometrik modellerdeki katsayılar, Engle-Granger yöntemi ve Dinamik En Küçük Kareler yöntemi ile tahmin edilmiştir. 
Çalışmanın içeriğinde dört bölüm bulunmaktadır. Giriş bölümünü takiben birinci bölümde literatür taraması yapılmıştır. İkinci bölümde çalışmada kullanılan test ve yöntemler hakkında bilgi verilmiştir. Üçüncü bölümde uygulama yapılmıştır. Dördüncü bölüm olan sonuç bölümünde analiz sonuçları özetlenmiştir.

\section{Literatür}

Seçim dönemlerinin ekonomi üzerindeki etkisini inceleyen birçok çalışma yapılmıştır. Telatar (2003) çalışmasında, 1986-1997 dönemi için Sanayi Üretim Endeksi, TÜFE, M1 para arzı ve kamu harcamaları değişkenlerini kullanarak, parlamenter sistemde hükümetlerin yeniden seçilebilmek için ekonomiyi manipüle edip etmediğini ve seçime gitme noktasında düşük enflasyon ve yüksek büyüme gibi işaretlerin etkili olup olmadığını araştırmıştır. Probit ve logit modellerin kullanıldığı çalışmada, karar alıcıların para ve maliye politikaları aracılığıyla ekonomiyi manipüle ettiği hipotezi doğrulanmıştır.

Akçoraoğlu ve Yurdakul (2004) çalışmalarında, 1987-2003 döneminde enflasyon, para arzı, döviz kuru, bütçe açığı, büyüme ve yatırım değişkenlerini kullanarak politik iş çevrimlerinin varlığını, partizan etkileri de dikkate alarak araştırmışlardır. Çalışmada eşbütünleşme analizi yapıllmış ve Hendry’nin Genelden Özele modelleme yöntemi kullanılmıştır. Araştırma sonucunda politik iş çevrimleri hipotezinin yalnızca bütçe açığı üzerinde etkili olduğu görülmüştür.

Sezgin (2005) Türkiye ekonomisinde politik etkilerin varlığını 1950-2003 dönemleri için araştırdığ çalışmasında politik iş çevrimlerinin var olduğunu ve seçimlerin ekonomik büyüme üzerinde olumsuz etki yarattığını ortaya koymuştur. Ancak ekonomi üzerindeki bu manipülasyonun boyutu küçüktür ve zaman içerisinde azalma eğilimindedir.

Parlaktuna ve Bahçe (2006) çalışmalarında Türkiye için 1980-2006 dönemi aylık verilerini kullanarak, politik iş çevrimleri yaşanıp yaşanmadığını, Gayri Safi Yurtiçi Hasıla, devletin nihai tüketim harcamaları, faiz oranı, M1 para arzı ve enflasyon gibi makroekonomik verileri kullanarak En Küçük Kareler yöntemi ile araştırmışlardır. Çalışmanın sonucunda etkinin yalnızca faiz oranı ve enflasyon oranı gibi parasal göstergelerde görüldüğ̈ tespit edilmiştir. 
Kaplan (2006) çalışmasında 1993-2004 yılları arası ekonomik büyüme, işsizlik oranı ve enflasyon oranı verilerini kullanarak 27 gelişmekte olan ve 20 gelişmiş ülke için panel veri analizi yapılmış ve seçim dönemlerinde ekonomik bir manipülasyonun olup olmadığı araştırılmıştır. Elde edilen bulgularda politik iş çevrimlerinin varlığını destekler nitelikte kanıtlara rastlanmamıştır.

Karagöl ve Turhan (2008) çalışmalarında, borç stoku ve savunma harcamaları değişkenlerine ait 1960-2002 yıllık veriler kullanılarak, seçim dönemlerinde iktidarın ekonomik bir manipülasyona sebebiyet verip vermediği araştırılmıştır. Çalışmanın sonucunda seçim dönemlerinde artan savunma harcamalarının seçim sonrasında da devam ettiği ve bu harcamaların partizan etkilerden de etkilendiği sonucuna ulaşılmıştır.

Erdoğan ve Bozkurt (2009) çalışmalarında, 1986-2005 dönemleri için aylık verilerle M1 para arzı değişkeni kullanılarak seçim dönemlerinin parasal konjonktür hareketlerine yol açıp açmadı̆̆1 incelenmiştir. GARCH tekniğinin kullanıldığı çalışmada seçim dönemlerinde M1 para arzında anlamlı bir artış olduğu gözlenmiştir.

Sert (2009) çalışmasında, enflasyon oranı, kamu harcamaları, M2 para arzı, döviz kuru, faiz oranı ve Gayri Safi Yurtiçi Hasılanın 1988-2008 döneminde gerçekleştirilen beş genel seçimin politik iş çevrimlerine sebep olup olmadığını incelemiştir. Çalışmada Hendry’nin Genelden Özele modelleme yöntemi kullanılmış ve seçim dönemlerinde kamu harcamalarında artış gözlendiği sonucuna ulaşılmıştır.

Özkan ve Tarı (2010) çalışmalarında, 1985-2010 döneminde gerçekleştirilen altı milletvekili seçimlerinin Gayri Safi Yurtiçi Hasıla, kamu harcamaları ve M1 para arzı değişkenleri üzerindeki etkilerini geleneksel firsatçı model kapsamında incelemişlerdir. Otoregresif hareketli ortalamalar modelinin kullanıldığı çalışmada, politik iş çevrimleri literatürüyle uyumlu olarak seçim dönemlerinde bir etkinin olduğu ancak bu etkinin daha yakın dönemde gerçekleştirilen seçimlerde giderek zayıflamakta olduğu söylenmektedir. 
Klose (2012) çalışmasında, politik iş çevrimleri ve para politikası ilişkisini 16 OECD ülkesi için iki boyutlu asimetrik Taylor reaksiyon fonksiyonu yöntemini kullanarak araştırmıştır. Para politikasında politik iş çevrimlerinin varlığının ortaya koyulduğu çalışmada merkez bankalarının bağımsız olmadığı görüşü dikkat çekmektedir.

Efthyvoulou (2012) çalışmasında, Avrupa Birliği üyesi ülkelerde 1998-2007 yılları arasında politik iş çevrimlerinin varlığını panel veri analizi yöntemlerini kullanarak araştırmış ve seçim dönemlerinde politik amaçlı ekonomik manipülasyonların var olduğu sonucuna ulaşmıştır.

Altun (2014) çalışmasında, 1950-2010 dönemine ait yıllık verilerle kamu harcamalarının politik iş çevrimi yaratmak için kullanılıp kullanılmadığını hem oportünist hem de partizan bakış açısıyla araştırmıştır. Otoregresif hareketli ortalamalar modeli aracılığıyla yapılan analiz sonucunda, iktidarların seçim dönemlerinde kamu harcamalarını arttırma eğiliminde olduğu sonucuna ulaşılmıştır.

Gökdemir (2016) çalı̧̧masında, 1950-2013 dönemi için yıllık veriler kullanılarak enflasyon, işsizlik, Gayri Safi Yurtiçi Hasıla, genel bütçe gelirleri, genel bütçe giderleri, M2 para arzı ve belediye gelir ve giderleri değişkenleri ile politik iş çevrimlerinin varlığını araştırmıştır.

Altıok (2016) çalışmasında, 1980-2015 dönemi yıllık verileri ile politik iş çevrimlerinin varlığını araştırmıştır. Araştırmada enflasyon, işsizlik, ekonomik büyüme, kamu harcamaları, kamu gelirleri, dış borçlanma ve para arzı değişkenleri kullanılarak seçim öncesi ve sonrası için artış oranı rasyosu hesaplanmış ve buna göre politik iş çevrimlerinin varlığı değerlendirilmiştir. Analiz sonucunda politik iş çevrimlerine rastlanmadığı bulgusuna ulaşılmışıır.

Güdenoğlu (2018) çalışmasında, 1950-2016 yılları arası Gayri Safi Yurtiçi Hasıla, kişi başı reel gelir, enflasyon oranı, para arzı, emisyon hacmi, faiz oranı ve kamu harcamaları değiş̧kenleri kullanılmış ve makroekonomik çıktı ve politika değişkenlerinde seçim bazlı bir manipülasyonun varlığını sınamıştır. ARIMA modellerinin kullanıldığı çalışmada politik iş çevrimlerinin geçerli olduğu ortaya koyulmuş̧tur. 
Yılmaz ve Yılmaz (2018) yaptıkları çalışmada, Türkiye'deki yerel seçimlerin işsizlik oranı ve enflasyon değişkenleri arasındaki ilişkisine bakılmıştır. 2005-2018 dönemleri için bölgesel ekonomik hoşnutsuzluk endeksini hesaplayarak, politik iş çevrimleri kapsamında incelemişlerdir. Çalışmanın sonucunda bölgesel hoşnutsuzluk endeksinin oy verme davranışı üzerinde güçlü bir etkisi olduğu saptanmıştır.

Tayyar (2020) çalışmasında, 1987-2015 dönemi reel para arzı, yurtiçi krediler ve enflasyon oranına ait aylık verileri kullanarak iktidarın makroekonomik göstergelerin avantaj sağladığı dönemlerde erken seçime gitme eğilimi gösterip göstermediğini araştırmıştır. ARIMA analizinin kullanıldığı çalışmanın sonucunda, iktidarın erken seçime gitmek için makroekonomik göstergelerin avantajından yararlanarak ekonomik manipülasyona sebep olduğu sonucuna ulaşılmıştır.

Kahveci ve Pelek (2021) çalışmasında, seçimlerin asgari ücret üzerinde etkili olup olmadığını 1975-2019 dönemine ait yıllık verileri kullanarak politik iş çevrimleri kapsamında incelemişlerdir. Araştırmanın sonucunda asgari ücretin politik bir enstrüman olarak kullanıldığı sonucuna ulaşılmıştır.

\section{Yöntem}

\section{1. Birim Kök Testleri}

Bir serinin, zaman içerisinde standart bir değer alması ya da beklenen değere yakınsaması durağanlık kavramını ifade eder. Serinin ortalaması, varyansı ve kovaryansı zamana bağlı olarak değişkenlik gösteriyorsa o serinin durağan olmadığı söylenebilir. Değişkenlerin zamana bağlılıklarının durağanlık yönünden incelenmesi oldukça önemlidir. Çoğu ekonomik ve finansal zaman serisi trend içerir ve durağan olmama özelliği sergiler. Literatürde çoğu ekonomik ve finansal verilerin birim kök ile karakterize edildiğine dair araştırmalar bulunmaktadır. Bu araştırmaların sonucunda bu verilerle yapılan çalışmalar sahte regresyona yani aslında anlamlı olmadığı halde anlamlıymış gibi görünen sonuçlara yol açabileceği öne sürülmektedir. Bu yüzden durağanlık testlerinin yapılması oldukça büyük önem taşımaktadır (Mushtaq, 2011). Bu çalışmada 
durağanlık tespiti için Augmented Dickey Fuller (ADF) birim kök testi ve Zivot-Andrews (1992) yapısal kırılmalı birim kök testi kullanılmıştır.

\section{2. Engle-Granger İki Aşamalı Tahmin Yöntemi}

İki değişken arasındaki uzun dönemli ilişki araştırılırken, modelde yer alan değişkenlerin birinci sıra fark durağan yani I(1) olması gerekir. Yöntem iki aşamadan oluşur. Birinci aşamada model katsayıları Klasik En Küçük Kareler (KEKK) yöntemi ile tahmin edilir ve hata terimi elde edilir. İkinci aşamada, birinci aşamadan elde edilen hata terimine DF ve ADF testi uygulanır. Eğer hata terimi düzeyde durağan bulunursa yani I(0) olursa, birinci aşamada yer alan modeldeki katsayılar uzun dönem denge katsayılarıdır (Engle-Granger, 1987).

\subsection{Dinamik En Küçük Kareler Yöntemi (DEKK)}

Dinamik EKK yöntemi 1991 yılında Saikkonen'in çalışmasında geliştirilen ve Stock-Watson (1993) çalışmasıyla katkı sağlanan bir yöntemdir. Bu yöntem EKK yönteminde meydana gelen küçük örneklem ve dinamik yapının göz ardı edilmesi sorununu ortadan kaldırmaktadır. Ayrıca çoğu hata terimi tabanlı testlerin aksine aynı dereceden durağan olmayan serilerde de kullanılabilmektedir (Jackman ve Lorde, 2010: 2-3). Bu yöntem, sağlam (robust) tek denklem yaklaşımıdır. DEKK regresörler arasındaki olası eşanlılık yanlılığg durumunu düzeltir. $\Delta X_{t}$ 'nin gecikmeli değerlerinin ve öncüllerinin alınmasıyla içsellik sorununu ortadan kaldırmaktadır. Uzun dönem ilişkisinin tahmini aşağıdaki gibi gösterilebilir:

$$
Y_{t}=X_{t}^{\prime} \beta+D_{1 t}^{\prime} \gamma_{1}+\sum_{j=-q}^{r} \Delta X_{t+j}^{\prime} \delta+v_{1 t}
$$

Elde edilen tahmin edici $\theta_{\text {DEKK }}^{\prime}=\left(\beta^{\prime}, \hat{\gamma}^{\prime}\right)^{\prime}$ şeklindedir (Yurdakul, 2018: 64). 


\subsection{Logit Model}

Bağımlı değişkenin yalnızca 0 ve 1 değerini aldığı modeller, ikili nitel yahut ikili tepki modelleri olarak adlandırılır. İkili nitel modellerden en sık başvurulanlardan biri logit model ya da diğer adıyla lojistik regresyon modelidir. $\mathrm{Bu}$ model birikimli lojistik dağılım fonksiyonuna dayandırılarak açıklanmaktadır.

$$
\begin{aligned}
& P_{i}=E\left(Y_{i} \backslash X_{i}\right)=\beta_{1}+\beta_{2} X_{i} \\
& P_{i}=E\left(Y_{i}=1 \backslash X_{i}\right)=\frac{1}{1+e^{-\left(\beta_{1}+\beta_{2} X_{i}\right)}}=\frac{1}{1+e^{-Z i}}
\end{aligned}
$$

Yukarıdaki ifadelerde $P_{i}$ açıklayıcı değişkeni ifade eden bireylerin tercihlerini yansıtan olasılık değeridir. $Z_{i}$ değişkeninin, $-\infty$ ile $+\infty$ arasında değerler alması ile $P_{i}$ de 0 ile 1 arasında hareket eder. Ancak $P_{i}$ ve $Z_{i}$ arasındaki ilişki doğrusal bir ilişki değildir.

\section{Uygulama}

Bu çalışmanın amacı 2002:04-2020:04 döneminde Türkiye' de yapılan seçimlerin (genel ve yerel) seçilen bazı makro-ekonomik değişkenler üzerindeki etkilerini araştırmaktır. Bu amaçla eşanlı ekonometrik modeller kurulmuştur ve aşağıda verilmiştir:

$$
\begin{aligned}
& \text { lihracat }=a_{10}+a_{11} \text { lyatirim }+a_{12} \text { ldolar }+u_{1} \\
& \text { lgsyh }=a_{20}+a_{21} \text { lyatirim }+a_{22} \text { lkamu }+u 2 \\
& \text { ltefe }=a_{30}+a_{31} \text { lm } 2+a_{32} \text { ldolar }+a_{33} \text { lgsyh }+u_{3} \\
& \text { lissiz }=a_{40}+a_{41} \text { ltefe }+a_{42} \text { lyatirim }+a_{43} \text { lihracat }+u_{4} \\
& \text { ltakiptekikredi }=a_{50}+a_{51} \text { lissiz }+a_{52} \text { ltefe }+a_{53} \text { lyatirim }+u_{5}
\end{aligned}
$$

Yukarıda ifade edilen ekonometrik modellerde yer alan değişkenlerin doğal logaritmaları alınarak ve başına “ $l$ " harfi konulması ile gösterilerek analize dahil edilmiştir. Seçilen değişkenler ülkelerin makroekonomik yapısını analiz etmek için literatürde sıklıkla kullanılan değişkenlerdir. Her bir 
içsel değişken için iktisadi kurama uygun şekilde dışsal değişkenler seçilmiştir. Modellerde kullanılan değişkenlerin seçiminde "kamu tercihi" teorisi kapsamında yapılan çalışmalarda sıkça kullanılan değişkenlerin yer almasına özen gösterilmiş ve modelleme aşamasında çeşitli iktisat teorilerinden, analize en uygun olanları kullanılmıştır.

Çalışmada değiş̧kenlere ait veriler ve verilerin elde edildiği kaynaklar aşağıdaki tabloda yer almaktadir.

Tablo 1: Değiş̧kenler ve Veri Kaynakları

\begin{tabular}{lll}
\hline Değişken & Gösterim & Veri Kaynağı \\
\hline İhracat (Bin TL) & lihracat & TCMB EVDS \\
\hline Gayrisafi Yurtiçi Hasıla (Bin TL) & lgsyh & TCMB EVDS \\
\hline Toptan Eşya Fiyat Endeksi & ltefe & TCMB EVDS \\
\hline İşsiz Sayısı (Bin kişi) & lissiz & TÜİ \\
\hline Takipteki Krediler (Milyon TL) & ltakipkredi & BDDK \\
\hline Yatırım Harcamaları (Bin TL) & lyatirim & TCMB EVDS \\
\hline Kamu Harcamaları (Bin TL) & lkamu & TCMB EVDS \\
\hline Döviz Kuru (1 Dolar=...TL) & ldolar & TCMB EVDS \\
\hline M2 Para Arzı(Bin TL) & lm2 & TCMB EVDS \\
\hline
\end{tabular}

(4.1) nolu modelde ihracat, yatırım harcamaları ve döviz kuru ile açıklanmıştır. Dış dünyaya açık bir ekonomide ihracat oldukça önemli bir göstergedir ve yurtiçindeki ekonomik aktörlerin başka ülkelere vermiş olduğu hizmet ve satmış olduğu mallardır. Yatırım harcamaları, yurtiçi ekonomik unsurlarının sermaye mal alımlarını ve stoklara yaptığı yatırım miktarını ifade eder. Uzun vadede gelir yaratması umulan mallar ve hazır üretimleri kapsayan yatırım harcamalarının artmasının, üretime olumlu katkıda bulunarak ihracat miktarını arttırması ekonomik açıdan beklenen bir durumdur. Döviz kurları da dış ticaret üzerinde oldukça belirleyici bir rol oynamaktadır. Döviz kurunda ortaya çıkan artışlar yani paranın değerinin düşmesi ihracatı artırıcı bir etki yaratacaktır. 
(4.2) nolu modelde yatırım harcamaları ve kamu harcamalarının, Gayri Safi Yurtiçi Hasıla üzerindeki etkisi incelenmektedir. Hükümetler, yatırım harcamalarının artmasını sağlayarak yüksek büyüme oranları yakalamayı hedeflemektedir. Bunu sağlamanın en iyi yolu da tüketimde azalma yoluna gidip tasarrufları arttırmaktan geçer. Yatırım harcamaları pozitif dışsallıkların ortaya çıkmasını sağlayarak daha üretken bir ekonomi oluşturur (Altunç, 2011: 148). Üretken bir ekonominin oluşması demek ise Gayri Safi Yurtiçi Hasılanın pozitif bir ivme yakalamasını sağlamak anlamına gelmektedir. Böylelikle yatırım harcamaları ve Gayri Safi Yurtiçi Hasıla arasında pozitif bir ilişki olduğu söylenebilir. Barro (1990) çalışmasında kamu harcamalarının, ekonomik büyüme üzerinde olumlu bir etki yaratacağını öne sürmektedir. Ancak kamu harcamalarının niceliği kadar niteliği de önemlidir. Eğer verimli şekilde yürütülmeyen kamu harcamaları söz konusuysa büyümenin olumsuz etkilenmesiyle de karşılaşılabilir. Dolayısıyla kamu harcamalarının etkin kullanımında Gayri Safi Yurtiçi Hasılada bir artış söz konusu olacağı düşünüldüğünde iki değişken arasında pozitif yönlü bir ilişki olduğu yorumu yapılabilir.

(4.3) nolu modelde enflasyonu temsilen Toptan Eşya Fiyat Endeksi (TEFE) alınmıştır. Modelde TEFE’yi açıklamak için M2 para arzı, döviz kuru ve Gayri Safi Yurtiçi Hasıla değişkenleri kullanılmıştır. Para arzı ile enflasyon arasında pozitif yönlü bir ilişki beklenmektedir. Klasik ve Neoklasik yaklaşıma göre enflasyon, Fisher miktar kuramına dayandırılmaktadır. Bu kuram, paranın arz seviyesindeki artışların enflasyonu arttıracağı görüşünü ortaya koymaktadır. Ayrıca döviz kurunda meydana gelecek bir artışında fiyatları arttırması beklenmektedir. Enflasyon ve Gayri Safi Yurtiçi Hasıla arasındaki ilişki uzunca süredir ekonomi literatüründe bir tartışma konusudur. Bir dönem enflasyonun büyümeyi pozitif yönlü etkilediği görüşü yaygın olarak benimsenmekteydi. Yakın dönemde ise daha çok negatif yönlü bir ilişkinin üzerinde durulmaktadır (Karaca, 2003: 247).

(4.4) nolu modelde işsizlik üzerinde enflasyon, yatırım ve kamu harcamalarının nasıl bir etki yaratacağı araştırılmak istenmiştir. Daha önce de ifade edildiği gibi politik iş çevrimleri yazınında da temel anlayış işsizlik ve enflasyon arasında Phillips eğrisine dayanan ilişki üzerine kurulmaktadır. Bu açıdan içsel değişken olarak enflasyonun seçilmesi oldukça akla yatkındır. Phillips eğrisi işsizlik enflasyon ilişkisini ters yönlü olarak ele almaktayken, bu durumun her zaman geçerli olmadığı, işsizlik ve enflasyonun eşzamanlı olarak yaşanabileceğini de ortaya koyan 
pek çok çalışma yapılmıştır. Keynesyen anlayışta kamu ve yatırım harcamalarının arzın ana belirleyicilerinden olduğu öne sürülmektedir. Kamu ve yatırım harcamalarındaki artışın arzı arttıracak olması ekonomik iyileştirme sağlar. Ekonomik birimler de ekonomik durumlarında gelişme sağlayarak istihdam yaratabilir. Böylelikle bu harcamalardaki artışın, işsizliği azaltıcı etki yaratması beklenmektedir. İşsizlik sorununun önüne geçebilmek için işsizliğin belirleyicinin araştırılması oldukça büyük önem arz etmektedir (Yalta ve Yalta, 2019: 105; Al-Atwari, 2019: 10).

(4.5) nolu modelde bankacılık sektörü açısından temel risk göstergesi olarak düşünülen takipteki krediler, içsel değişken olarak seçilmiştir. Takipteki kredileri açıklamak için ise enflasyon, döviz kuru, yatırım harcamaları ve Gayri Safi Yurtiçi Hasıla değişkenleri kullanılmıştır. Enflasyon gelirleri düşürerek takipteki kredilerin artmasına sebep olabilmekte ve döviz kurunun ise ekonomik istikrarsızlık yaratarak borçların geri ödemelerini geciktirerek, risk oranını artırabilmektedir. Yatırım harcamaları da büyüme üzerindeki pozitif etkisiyle kredi riskini azaltan bir unsur olduğu düşünülerek modele dahil edilmiştir (Özciğer, 2020: 115).

Çalışmada, eşanlı modellerin öncelikle belirlenme durumu araştırılmalıdır. Bunun için sıra ve aşama koşullarına bakılması gerekir. Sıra koşulunda K-M $\geq \mathrm{G}-1$ koşulu geçerlidir. Eğer $\quad$ K$\mathrm{M}=\mathrm{G}-1$ ise model tam belirlenmiştir. $\mathrm{K}-\mathrm{M}>\mathrm{G}-1$ ise model aşırı belirlenmiştir. $\mathrm{K}-\mathrm{M}<\mathrm{G}-1$ ise model eksik belirlenmiştir. Eksik belirlenmiş modele hiçbir yöntem uygulanamaz. Sıra ve aşama koşulu sonuçları Tablo 2'de verilmiştir.

Tablo 2: Sıra ve Aşama Koşulu Sonucu ${ }^{1}$

\begin{tabular}{|l|ll|}
\hline lihracat & $9-3 \geq 5-1$ & AŞIRI BELİRLENME \\
\hline lgsyh & $9-3 \geq 5-1$ & AŞIRI BEL்̇LLENME \\
\hline ltefe & $9-4 \geq 5-1$ & AŞIRI BELI்RLENME \\
\hline
\end{tabular}

${ }^{1}$ Burada, K:Eşanlı modeldeki tüm (içsel+Önceden belli değişken) değişken sayısı: (9)

M: İncelen modeldeki tüm (içsel+Önceden belli değişken) değişken sayısı

G: Model sayıs1: (5)

İçsel değişkenler; lihracat, lgsyh, ltefe, lissiz, ltakipkredi

Dişsal değişkenler;lyatirim, ldolar, lm2, lkamu 


\begin{tabular}{|c|c|c|c|c|c|c|c|c|c|}
\hline lissiz & & $9-3 \geq$ & $5-1$ & ISSIRI BELİ $F$ & LENME & & & & \\
\hline ltakipkrec & & $9-5 \geq$ & $5-1$ & ŞIRI BELं। & LENME & & & & \\
\hline lihracat & Lgsyh & Ltefe & lissiz & ltakipkredi & lyatirim & Ldolar & lkamu & $\operatorname{lm} 2$ & Sabit \\
\hline 1 & 0 & 0 & 0 & 0 & $-a_{11}$ & $-a_{12}$ & 0 & 0 & $-a_{10}$ \\
\hline 0 & 1 & 0 & 0 & 0 & $-a_{21}$ & 0 & $-a_{22}$ & 0 & $-a_{20}$ \\
\hline 0 & $-a_{33}$ & 1 & 0 & 0 & 0 & $-a_{32}$ & 0 & $-a_{31}$ & $-a_{30}$ \\
\hline 0 & 0 & $-a_{41}$ & 1 & 0 & $-a_{42}$ & 0 & 0 & 0 & $-a_{40}$ \\
\hline 0 & 0 & $-a_{51}$ & $-a_{52}$ & 1 & $-a_{53}$ & 0 & $-a_{54}$ & 0 & $-a_{50}$ \\
\hline
\end{tabular}

Tablo 2'de bütün modeller aşırı belirlenmiştir. Aşama koşulunda G-1:5-1=4 (4x4) matrisinin elemanlarının sıfırdan farklı olması gerekir. Aşama koşulu da sağlanmıştır. (4.3), (4.4) ve (4.5) nolu modellerde bir içsel değişken, başka bir içsel değişkenin fonksiyonu olduğu için bu modeller 2AEKK(İki Aşamalı En Küçük Kareler) ${ }^{2}$ yöntemi ile; (4.1) ve (4.2) nolu modeller bir içsel değişken sadece dişsal değişkenlerin birer fonksiyonu olduğu için EKK (En Küçük Kareler) yöntemi ile tahmin edilmesi gerekir. Eğer bir içsel değişken, başka bir içsel değişkenin fonksiyonu olarak ifade edildiğinde EKK yöntemi uygulanırsa eşanlı denklem sapması sorunu ile karşılaşılır. Dolayısıyla (4.3), (4.4) ve (4.5) nolu modellerde içsellik sorunu ile karşılaşılmıştır. Bununla birlikte değişkenlerin durağanlığı da önemli bir konudur. Eşanlı modellerde yer alan değişkenler makro büyüklükler oldukları için içsel ve dışsal değişkenlerin durağan olmama ihtimali çok yüksektir. Bu nedenle modellerde yer alan değişkenlerin durağan olup olmadıklarını ortaya koyabilmek amacıyla ADF (Augmented Dickey-Fuller) birim kök testi ve ayrıca ZA(1992) yapısal kırılma testi yapılmıştır. Test sonuçları Tablo 3'te verilmiştir. Tablo 3'deki ZA testi sonucuna göre takipteki krediler, TEFE, GSYH, ihracat serileri kırılmaya rağmen durağan değilken; işsiz sayısı kırılmaya rağmen durağan bir seridir. ADF birim kök testi sonucuna göre de bütün değişkenler birinci sıra fark durağandır.

${ }^{2}$ 2AEKK yöntemi iki aşamalıdır. Yöntemin birinci aşamasında modelin sağ tarafında yer alan içsel değişken (ler), eşanlı modeldeki tüm önceden belli (dışsal+gecikmeli içsel) değişkenlerin birer fonksiyonu olarak alınır. EKK yöntemi ile katsayılar tahmin edilir ve içsel değişkenin tahmin değeri (şapka) bulunur. İkinci aşamada ise modelin sağ tarafında yer alan içsel değişkenin kendi değeri yerine tahmini değeri yerine konularak, model katsayıları EKK ile tahmin edilir. 
Tablo 3: ADF Birim Kök Testi Sonucu

\begin{tabular}{|c|c|c|c|c|}
\hline & \multicolumn{2}{|c|}{ ADF (Sabit+Eğim) ${ }^{3}$} & \multicolumn{2}{|c|}{ Zivot-Andrews ${ }^{4}$} \\
\hline Değişkenler & Düzey & Birinci Sıra Fark & Model C & Sonuç \\
\hline lihracat & $-1.96 \mathrm{k}: 3$ & $-10.07 * * \mathrm{k}: 2$ & $\begin{array}{l}-2.75 \mathrm{k}: 4(2012: 02) \\
{[-5.57,-5.08,-4.82]}\end{array}$ & $\begin{array}{l}\text { Kırılmaya } \\
\text { rağmen } \\
\text { durağan değil. }\end{array}$ \\
\hline lgsyh & $-1.22 \mathrm{k}: 4$ & $-3.75 * * \mathrm{k}: 3$ & $\begin{array}{l}-3.30 \mathrm{k}: 4(2013: 01) \\
{[-5.57,-5.08,-4.82]}\end{array}$ & $\begin{array}{l}\text { Kırılmaya } \\
\text { rağmen } \\
\text { durağan değil. }\end{array}$ \\
\hline ltefe & $0.92 \mathrm{k}: 0$ & $-6.43 * * \mathrm{k}: 0$ & $\begin{array}{l}-4.36 \mathrm{k}: 1(2016: 02) \\
{[-5.57,-5.08,-4.82]}\end{array}$ & $\begin{array}{l}\text { Kırılmaya } \\
\text { rağmen } \\
\text { durağan değil }\end{array}$ \\
\hline
\end{tabular}

\footnotetext{
${ }^{3} \mathrm{ADF}$ birim kök testi için kullanılan model aşağıdadır:

$\Delta y_{t}=\mu+\alpha y_{t-1}+\beta_{i} \sum_{i=1}^{k} \Delta y_{t-i}+\varepsilon_{t}$
}

Burada birim kökün varlığı araştııldı ğında hipotezler aşağıdaki gibi oluşturulur.

$\mathrm{H}_{0}: \alpha=0$ Seri durağan değildir.

$\mathrm{H}_{1}: \alpha<0$ Seri durağandır.

ADF regresyonlarında birim kökün varlı̆̆ı, DF testinde olduğu gibi hesaplanan kritik değerlerle test edilir (Enders, 1995).

${ }^{4}$ ZA (1992) testinin iki önemli açıklaması vardır. Birincisi, kırılma noktası içsel olarak tahmin edilmektedir. İkincisi, bir zaman kırılma kukla değişkeni $\left(\mathrm{D}\left(\mathrm{T}_{\mathrm{B}}\right)_{\mathrm{t}}\right)$ yoktur. ZA (1992) çalışmasında tahmin edilen kırılma noktası ile ilgili test istatistiklerinin asimtotik dağılımı mevcuttur. Modeller aşağıdadır:

Model A:

$$
y_{t}=\mu^{A}+\alpha^{A} y_{t-1}+\beta^{A} t+\theta^{A} D U_{t}(\lambda)+\sum_{j=1}^{k} d_{j}^{A} \Delta y_{t-j}+\varepsilon_{t}
$$

Model B:

$$
y_{t}=\mu^{B}+\alpha^{B} y_{t-1}+\beta^{B} t+\gamma^{B} D T_{t}^{*}(\lambda)+\sum_{j=1}^{k} d_{j}^{B} \Delta y_{t-j}+\varepsilon_{t}
$$

Model C:

$$
y_{t}=\mu^{C}+\alpha^{C} y_{t-1}+\beta^{C} t+\theta^{C} D U_{t}(\lambda)+\gamma^{C} D T_{t}(\lambda)+\sum_{j=1}^{k} d_{j}^{C} \Delta y_{t-j}+\varepsilon_{t}
$$




\begin{tabular}{|l|l|l|l|l|}
\hline lissiz & $-0.62 \mathrm{k}: 9$ & $-3.30 * * \mathrm{k}: 8$ & $\begin{array}{l}-5.31 \mathrm{k}: 4(2011: 03) \\
{[-5.57,-5.08,-4.82]}\end{array}$ & $\begin{array}{l}\text { Kurılmaya } \\
\text { rağmen } \\
\text { durağan }\end{array}$ \\
\hline ltakipkredi & $-3.24 \mathrm{k}: 1$ & $-4.95 * * \mathrm{k}: 0$ & $\begin{array}{l}-3.95 \mathrm{k}: 1(2011: 01) \\
{[-5.57,-5.08,-4.82]}\end{array}$ & $\begin{array}{l}\text { Kurılmaya } \\
\text { rağmen } \\
\text { durağan değil. }\end{array}$ \\
\hline lyatirim & $-1.71 \mathrm{k}: 7$ & $-3.98^{* * \mathrm{k}: 6}$ & & \\
\hline lkamu & $-0.49 \mathrm{k}: 3$ & $-25.73 * * \mathrm{k}: 2$ & & \\
\hline ldolar & $2.36 \mathrm{k}: 0$ & $-7.12 * * \mathrm{k}: 0$ & & \\
\hline lm2 & $-2.02 \mathrm{k}: 0$ & $-4.53 * * \mathrm{k}: 1$ & & \\
\hline
\end{tabular}

** 0.01 ve 0.05 'te durağan.

Değişkenler birinci sıra fark durağan I(1) oldukları için, Eşbütünleşme analizine geçilmesi ve Engle-Granger yöntemi, Johansen yöntemi, ARDL sınır testi, Dinamik EKK yöntemi gibi yöntemlerin kullanılması gerekir. Bununla birlikte (4.3), (4.4) ve (4.5) nolu modellerde içsellik sorunu vardır ve bu sorunu bertaraf etmek amacıyla kullanılan yöntemlerden biri, Dinamik EKK yöntemidir. Dolayısıyla (4.3), (4.4) ve (4.5) nolu modellerdeki katsayılar 2AEKK yöntemi yerine Dinamik EKK yöntemi ile tahmin edilmiş; (4.1) ve (4.2) nolu modellerdeki katsayılar EKK yöntemi yerine Engle-Granger yöntemi ile tahmin edilmiştir. Tahmin sonuçları aşağıdaki tablolarda verilmiştir.

Tablo 4:İhracat Modeli ve GSYH Modeli Tahmin Sonuçları (Engle-Granger Yöntemi)

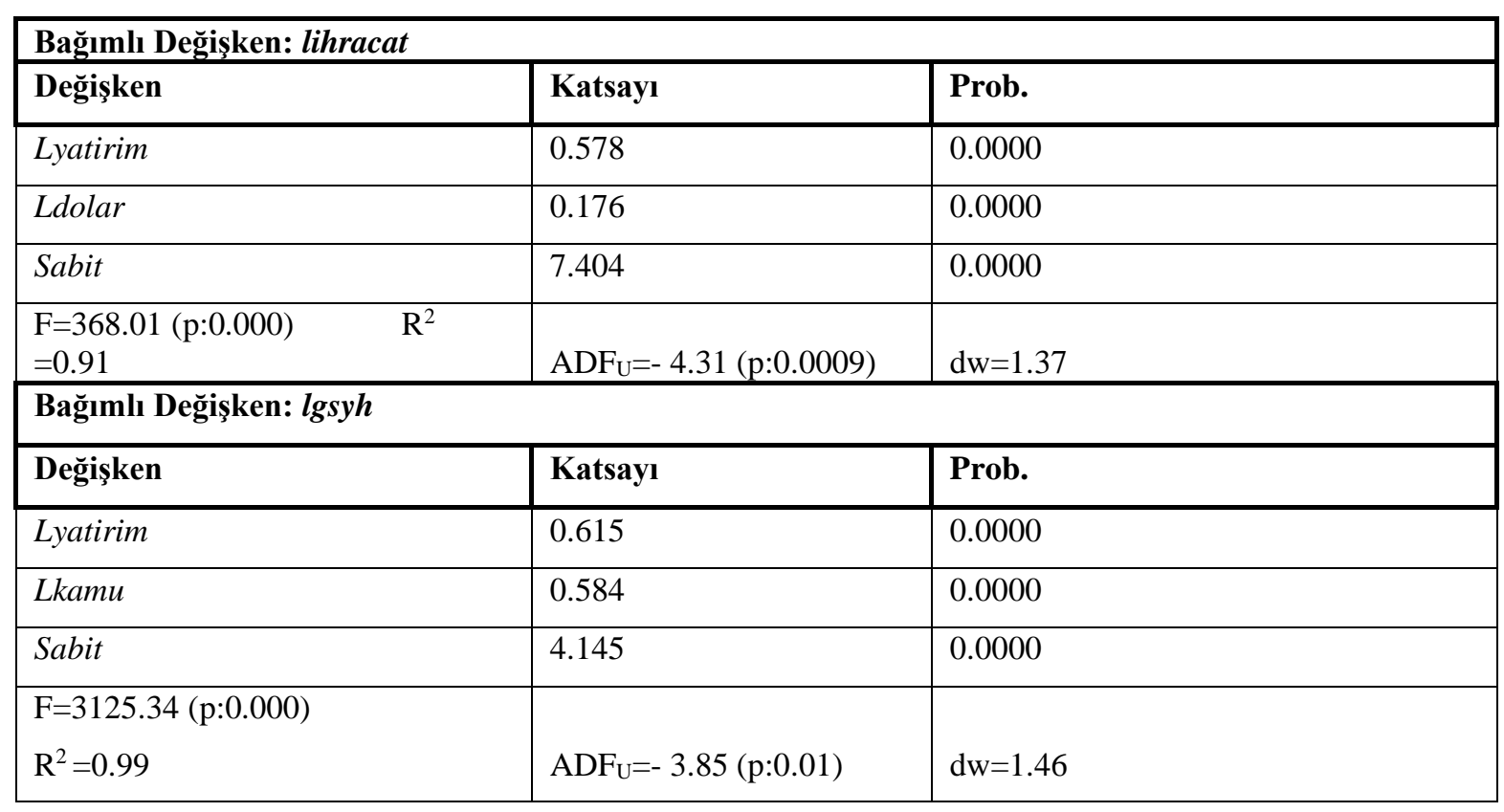


*GSYH değişkeni mevsimsel etkiden arındırılmıştır.

İhracat modelindeki katsayılar Engle-Granger yöntemi kullanılarak tahmin edilmiştir. Tahmin sonuçlarına göre, diğer değişken sabitken, döviz kurundaki \%1'lik artış, ihracatı $\% 0.176$ artııırken; yatırım harcamalarındaki \%1 lik artış, ihracatı \%0.578 artırmaktadır. Döviz kuru ve yatırım harcamaları yüzde 91 oranında ihracatı açıklamaktadır. F testine göre model tümüyle anlamlı, $t$ testine göre katsayılar anlamlıdır. Yatırım harcamaları ve döviz kurunun pozitif katsayılara sahip olması iktisadi beklentiler ile uyumludur.

GSYH modelindeki katsayılar Engle-Granger yöntemi kullanılarak tahmin edilmiştir. Diğer değişken sabitken, yatıım harcamalarındaki \%1'lik artış, GSYH'yı \%0.615 artırırken; kamu harcamalarındaki \%1' lik artış, GSYH'yı \%0.584 artırmaktadır. Modelin açıklama gücü yüksektir $\left(\mathrm{R}^{2}=0.99\right)$. Model tümüyle anlamlı ve katsayılar anlamlıdır. Katsayılar, teorik beklentiler ile uyumludur.

Tablo 5: TEFE, İşsiz Sayısı ve Takipteki Krediler Modelleri Tahmin Sonuçları (DEKK Yöntemi)

\begin{tabular}{|l|l|l|}
\hline Bağımlı Değişken: ltefe & Katsayı & Prob. \\
\hline Değişken & 0.153 & 0.0000 \\
\hline lm2 & 0.353 & 0.0000 \\
\hline Ldolar & 0.299 & 0.000 \\
\hline Lgsyh & 8.911 & 0.0000 \\
\hline Sabit & $\mathrm{R}^{2}=0.99$ & \\
\hline Gecikme:1 Öncül:1 & \multicolumn{2}{|l|}{} \\
\hline Bağımlı Değişken: lissiz & Katsayı & Prob. \\
\hline Değişken & 1.83 & 0.0000 \\
\hline Ltefe & -0.725 & 0.0013 \\
\hline Lyatirim & -0.413 & 0.0133 \\
\hline Lihracat & -5.26 & 0.0453 \\
\hline Sabit & $\mathrm{R}^{2}=0.89$ & \\
\hline Gecikme:1 Öncül:1 & \\
\hline Bağımlı Değişken: ltakiptekikrediler & \\
\hline Değişken & Katsayı & Prob. \\
\hline Lissiz & 0.994 & 0.0000 \\
\hline Ltefe & 1.776 & 0.0000 \\
\hline Lyatirim & -0.145 & 0.095 \\
\hline Sabit & -27.30 & 0.0000 \\
\hline Gecikme:1 Öncül:1 & $\mathrm{R}^{2}=0.99$ & \\
\hline
\end{tabular}


Tablo 5'te üç farklı model vardır ve modellerin katsayıları Dinamik EKK yöntemi ile tahmin edilmiştir. Fiyat (TEFE) modeline bakıldığında, diğer değişkenler sabitken, GSYH \%1 arttığında, TEFE \%0.299 artmaktadır. Döviz kuru \%1 artığında, TEFE \%0.353 artarken, para arzı \%1 artı̆̆ında TEFE \%0.153 artmaktadır. Modelin açıklama gücü yüksektir ve katsayılar anlamlıdır. M2 para arzı, döviz kuru ve Gayri Safi Yurtiçi Hasılanın pozitif katsayılara sahip olması iktisadi beklentiler ile uyumludur.

İşsiz sayısına ait modele bakıldığında, diğer değişkenler sabitken; yatırım harcamalarındaki \%1'lik artış, işsiz sayısını \%0.72 azaltırken; ihracattaki \% 1'lik artış, işsiz sayısını \%0.41 azaltmaktadır. TEFE'deki \%1'lik artış, işsiz sayısını \%1.83 artırmaktadır. Modelin açıklama gücü yüksektir ve katsayilar anlamlıdır.

Takipteki krediler modeline bakıldığında, diğer değişkenler sabitken; işsiz sayısında\%1'lik artış, takipteki kredileri \% 0.99 artıırken, TEFE'deki \%1'lik artış, takipteki kredileri \%1.776 artırmaktadır. Yatırım harcamalarındaki \%1'lik artış, takipteki kredileri \%0.145 azaltmaktadır. Modelin açıklama gücü yüksektir. Katsayılar anlamlı ve teorik beklentilerle uyumludur.

Yukarıda tahmin edilen eşanlı modellerin katsayıları iktisadi beklentileri karşılamaktadır. Modeller tümüyle anlamlı ve katsayılar istatistiksel bakımdan anlamlıdır. Modellerin açıklama gücü yüksektir. Dolayısıyla bundan sonraki aşamada tahmin edilen bu modellere seçim kuklaları eklenerek, seçimlerin makro-ekonomik değişkenler üzerindeki etkileri araştırılmıştır.

\subsection{Seçim Kuklaları ile Elde Edilen Tahminler}

Politik iş çevrimleri literatüründe seçimlerin etkilerinin araştırılması için kukla değişkenler kullanılmaktadır. Bunun için üç adet seçim kuklası modele katılarak model katsayıları tahmin edilmiştir. Modelde yer alan kuklaların nasıl isimlendirildiği aşă̆ıdaki tabloda açıklanmaktadır. 
Tablo 6: Seçim Kuklalarının Adlandırılması.

\begin{tabular}{|l|l|}
\hline genelsecim & $\begin{array}{l}\text { Genel Seçim yapıldığı dönemlerde 1, diğer dönemlerde 0 değerini alan } \\
\text { kukla değişken. (2002:04, 2007:03, 2011:02, 2015:02, 2015:04, 2018:02) }\end{array}$ \\
\hline yerelsecim & $\begin{array}{l}\text { Yerel Seçim yapıldığ1 dönemlerde 1, diğer dönemlerde 0 değerini alan } \\
\text { kukla değişken. (2004:01, 2009:01, 2014:01, 2019:01) }\end{array}$ \\
\hline secim & $\begin{array}{l}\text { Genel ya da yerel seçimin yapıldığ1 dönemlerde 1, diğer dönemlerde 0 } \\
\text { değerini alan kukla değişken. (2002:04, 2004:01, 2007:03, 2009:01 } \\
2011: 02,2014: 01,2015: 02,2015: 04,2018: 02,2019: 01)\end{array}$ \\
\hline
\end{tabular}

Seçim kuklalarının ihracat, GSYH, TEFE, işsiz sayısı ve takipteki krediler üzerinde etkili olup olmadıklarını araştırmak amacıyla (4.1) ve (4.2) nolu modellere ayrı ayrı kukla değişkenler eklenerek, Engle-Granger yöntemi ile katsayılar tahmin edilmiştir. (4.3), (4.4) ve (4.5) nolu denklemlere de ayrı ayrı kukla değişkenler eklenerek, Dinamik EKK yöntemi ile katsayılar tahmin edilmiştir. Tahmin sonuçları aşağıdaki tablolarda verilmiştir ${ }^{5}$.

Tablo 7: İhracat Modeli için Seçim Kuklalarının Yer Aldığı Tahmin Sonuçları (EngleGranger Yöntemi)

\begin{tabular}{|c|c|c|c|c|c|c|c|c|}
\hline \multicolumn{9}{|c|}{ Bağımlı Değişken: lihracat } \\
\hline \multicolumn{3}{|c|}{ Genel Seçim Kuklası } & \multicolumn{3}{|c|}{ Yerel Seçim Kuklası } & \multicolumn{3}{|c|}{ Seçim Kuklası } \\
\hline Değişken & Katsay 1 & Prob & Değişken & Katsayı & Prob & Değişken & Katsay1 & Prob \\
\hline lyatirim & 0.767 & 0.0000 & lyatirim & 0.771 & 0.0000 & lyatirim & 0.763 & 0.0000 \\
\hline ldolar & 0.151 & 0.0000 & ldolar & 0.172 & 0.0000 & ldolar & 0.197 & 0.0000 \\
\hline genelsecim & -0.09 & 0.0470 & yerelsecim & 0.114 & 0.0381 & secim & -0.011 & 0.094 \\
\hline Sabit & 2.385 & 0.0000 & Sabit & 2.300 & 0.0000 & Sabit & 2.434 & 0.0000 \\
\hline $\mathrm{F}=427.50$ & $\mathrm{R}^{2}=0.94$ & $\mathrm{dw}=1.31$ & $\mathrm{~F}=429.87$ & $\mathrm{R}^{2}=0.94$ & $\mathrm{dw}=0.81$ & $\mathrm{~F}=402.51$ & $\mathrm{R}^{2}=0.94$ & $\mathrm{dw}=0.84$ \\
\hline $\begin{array}{l}\mathrm{ADF}_{\mathrm{U}}=-2.95 \\
(\mathrm{p}: 0.06)\end{array}$ & & & $\begin{array}{l}\mathrm{ADF}_{\mathrm{U}}=-4.23 \\
(\mathrm{p}: 0.001)\end{array}$ & & & $\begin{array}{l}\mathrm{ADF}_{\mathrm{U}}=-4.29 \\
\text { (p:0.001) }\end{array}$ & & \\
\hline
\end{tabular}

${ }^{5}$ Bütün modeller sıra ve aşama koşuluna göre aşırı belirlenmiştir. 
Tablo 7'de genel seçimleri ifade eden kukla değişkenin katsayısının negatif olması, genel seçimlerde ihracatın azalma eğiliminde olduğu anlamına gelmektedir. Kukla değişkene ait katsayı anlamlı bulunmuştur. Genel seçimlerin ihracat üzerinde politik iş çevrimi yarattı̆̆ söylenebilir. Hem genel hem de yerel seçimlerin bir arada alındı̆̆ "seçimlerin” ihracat üzerindeki etkisi, genel seçimlere benzerdir. Seçimlerde de ihracat azalma eğilimindedir ve kukla değişkeninin katsayısı anlamlı bulunmuştur. Yerel seçimlerde ise ihracat artma eğilimindedir ve kukla değişkene ait katsayı anlamlı bulunmuştur. Dolayısıyla tüm seçimlerin ihracat üzerinde politik iş çevrimi yarattığı söylenebilir.

Tablo 8: GSYH Modeli için Seçim Kuklalarının Yer Aldığı Tahmin Sonuçları (EngleGranger Yöntemi)

\begin{tabular}{|c|c|c|c|c|c|c|c|c|}
\hline \multicolumn{9}{|c|}{ Bağımlı Değișken: lgsyh } \\
\hline \multicolumn{3}{|c|}{ Genel Seçim Kuklası } & \multicolumn{3}{|c|}{ Yerel Seçim Kuklası } & \multicolumn{3}{|c|}{ Seçim Kuklası } \\
\hline Değişken & Katsayı & Prob & Değişken & Katsay 1 & Prob & Değişken & Katsay 1 & Prob \\
\hline lyatirim & 0.304 & 0.0000 & lyatirim & 0.316 & 0.0000 & lyatirim & 0.297 & 0.0000 \\
\hline lkamu & 0.578 & 0.0000 & lkamu & 0.568 & 0.0000 & lkamu & 0.589 & 0.0000 \\
\hline genelsecim & -0.030 & 0.328 & yerelsecim & 0.059 & 0.1304 & secim & 0.0034 & 0.88 \\
\hline Sabit & 4.104 & 0.0000 & Sabit & 4.064 & 0.0000 & Sabit & 4.135 & 0.0000 \\
\hline $\mathrm{F}=1630.57$ & & & $\mathrm{~F}=1548.48$ & & & $\mathrm{~F}=1602.98$ & & \\
\hline $\begin{array}{l}\mathrm{ADF}_{\mathrm{U}}:-2.60 \\
(\mathrm{p}: 0.09)\end{array}$ & $\mathrm{R}^{2}=0.99$ & $\mathrm{dw}=0.87$ & $\begin{array}{l}\mathrm{ADF}_{\mathrm{U}}:-2.72 \\
\text { (p:0.07) }\end{array}$ & $\mathrm{R}^{2}=0.98$ & $\mathrm{dw}=0.95$ & $\begin{array}{l}\text { ADFu:-3.39 } \\
\text { (p:0.015) }\end{array}$ & $\mathrm{R}^{2}=0.98$ & $\mathrm{dw}=0.84$ \\
\hline
\end{tabular}

Tablo 8'de genel seçimlerde GSYH azalma eğiliminde, yerel seçimlerde ve seçimlerde GSYH artma eğilimindedir. Kukla değişkenlere ait katsayılar istatistiksel bakımdan anlamsızdır. Dolayısıyla tüm seçimlerin GSYH üzerinde politik iş çevrimi yaratmadığı söylenebilir.

Tablo 9: TEFE Modeli için Seçim Kuklalarının Yer Aldığı Tahmin Sonuçları (DEKK Yöntemi)

\begin{tabular}{|c|c|c|c|c|c|c|c|c|}
\hline \multicolumn{9}{|c|}{ Bağımlı Değişken: ltefe } \\
\hline \multicolumn{3}{|c|}{ Genel Seçim Kuklası } & \multicolumn{3}{|c|}{ Yerel Seçim Kuklası } & \multicolumn{3}{|c|}{ Seçim Kuklası } \\
\hline Değişken & Katsayı & Prob & Değişken & Katsayı & Prob & Değişken & Katsayı & Prob \\
\hline $\operatorname{lm} 2$ & 0.165 & 0.044 & $\operatorname{lm} 2$ & 0.114 & 0.058 & $\operatorname{lm} 2$ & 0.239 & 0.051 \\
\hline ldolar & 0.212 & 0.0038 & ldolar & 0.123 & 0.0055 & ldolar & 0.130 & 0.0042 \\
\hline
\end{tabular}


Seçimlerin Ekonomik Etkileri: Türkiye Üzerine Bir Uygulama

\begin{tabular}{|l|l|l|l|l|l|l|l|l|}
\hline lgsyh & 0.484 & 0.0000 & llgsyh & 0.491 & 0.0000 & lgsyh & 0.484 & 0.0000 \\
\hline genelsecim & 0.0097 & 0.6007 & yerelsecim & 0.006 & 0.922 & secim & 0.0085 & 0.841 \\
\hline Sabit & 6.645 & 0.0000 & Sabit & 6.552 & 0.0000 & Sabit & 6.648 & 0.0000 \\
\hline & & & & & & & & \\
\hline $\begin{array}{l}\text { Gecikme:1 } \\
\text { Öncül:1 }\end{array}$ & $\mathrm{R}^{2}=0.99$ & & $\begin{array}{l}\text { Gecikme: } 1 \\
\text { Öncül: } 1\end{array}$ & $\mathrm{R}^{2}=0.99$ & & $\begin{array}{l}\text { Gecikme: } 1 \\
\text { Öncül: } 1\end{array}$ & $\mathrm{R}^{2}=0.99$ & \\
\hline
\end{tabular}

Tablo 9'da genel seçim, yerel seçim ve seçimlerde TEFE artma eğilimindedir. Kukla değişkenlerin katsayıları da anlamsızdır. Dolayısıyla tüm seçimlerin TEFE üzerinde politik iş çevrimi yaratmadığı söylenebilir.

Tablo 10: İşsizlik Modeli için Seçim Kuklalarının Yer Aldığı Tahmin Sonuçları (DEKK Yöntemi)

\begin{tabular}{|c|c|c|c|c|c|c|c|c|}
\hline \multicolumn{9}{|c|}{ Bağımlı Değişken: lissiz } \\
\hline \multicolumn{3}{|c|}{ Genel Seçim Kuklası } & \multicolumn{3}{|c|}{ Yerel Seçim Kuklası } & \multicolumn{3}{|c|}{ Seçim Kuklası } \\
\hline Değişken & Katsayı & Prob & Değişken & Katsayı & Prob & Değişken & Katsay & Prob \\
\hline ltefe & 1.828 & 0.000 & ltefe & 1.709 & 0.0001 & ltefe & 0.827 & 0.0000 \\
\hline lyatirim & -0.719 & 0.0031 & lyatirim & -0.649 & 0.0112 & lyatirim & -0.722 & 0.0027 \\
\hline lihr & -0.411 & 0.0182 & lihr & -0.421 & 0.014 & lihr & -0.412 & 0.0181 \\
\hline genelsecim & -0.029 & 0.8513 & yerelsecim & 0.1103 & 0.68 & secim & 0.009 & 0.953 \\
\hline Sabit & -5.28 & 0.059 & Sabit & -4.267 & 0.162 & Sabit & -5.206 & 0.07 \\
\hline $\begin{array}{l}\text { Gecikme:1 } \\
\text { Öncül:1 }\end{array}$ & $\mathrm{R}^{2}=0.89$ & & $\begin{array}{l}\text { Gecikme:1 } \\
\text { Öncül:1 }\end{array}$ & $\mathrm{R}^{2}=0.90$ & & $\begin{array}{l}\text { Gecikme:1 } \\
\text { Öncül:1 }\end{array}$ & $\mathrm{R}^{2}=0.89$ & \\
\hline
\end{tabular}

Tablo 10'da genel seçimlerde işsiz sayısı azalma eğiliminde, ancak yerel ve seçimlerde işsiz sayısı artma eğilimindedir. Kukla değişkenlerin katsayıları da anlamsızdır. Dolayısıyla tüm seçimlerin işsiz sayısı üzerinde politik iş çevrimi yaratmadığı söylenebilir. 
Tablo 11: Takipteki Krediler Modeli için Seçim Kuklalarının Yer Aldığı Tahmin Sonuçları (DEKK Yöntemi)

\begin{tabular}{|c|c|c|c|c|c|c|c|c|}
\hline \multicolumn{9}{|c|}{ Bağımlı Değişken: ltakiptekikrediler } \\
\hline \multicolumn{3}{|c|}{ Genel Seçim Kuklası } & \multicolumn{3}{|c|}{ Yerel Seçim Kuklası } & \multicolumn{3}{|c|}{ Seçim Kuklası } \\
\hline Değişken & Katsay 1 & Prob & Değişken & Katsay & Prob & Değişken & Katsay 1 & Prob \\
\hline lissiz & 1.004 & 0.0000 & lissiz & 1.027 & 0.0000 & lissiz & 1.008 & 0.0000 \\
\hline lyatirim & -0.12 & 0.102 & lyatirim & -0.204 & 0.115 & lyatirim & -0.123 & 0.09 \\
\hline ltefe & 1.738 & 0.0000 & ltefe & 1.863 & 0.0000 & ltefe & 1.746 & 0.0000 \\
\hline genelsecim & -0.016 & 0.8894 & yerelsecim & -0.175 & 0.385 & secim & -0.075 & 0.503 \\
\hline Sabit & -27.09 & 0.0000 & Sabit & -27.96 & 0.0000 & Sabit & -27.20 & 0.0000 \\
\hline Gecikme:1 & $\mathrm{R}^{2}$ & & Gecikme: 1 & $\mathrm{R}^{2}$ & & Gecikme: 1 & $\mathrm{R}^{2}$ & \\
\hline Öncuil:1 & $=0.99$ & & Öncül:1 & $=0.99$ & & Öncül:1 & $=0.99$ & \\
\hline
\end{tabular}

Tablo 11'de genel seçimler, yerel seçimler ve seçimlerde takipteki krediler azalma eğilimindedir ve kukla değişkenlere ait katsayılar istatistiksel bakımdan anlamsızdır. Dolayısıyla tüm seçimlerin takipteki krediler üzerinde politik iş çevrimi yaratmadığı söylenebilir.

Bu çalışmada ayrıca işsizlik oranındaki, TEFE'deki yüzde artış oranındaki ve GSYH'daki yüzde artış oranındaki artışların genel seçim, yerel seçim ve seçim olma olasılığını ne yönde etkilediğini ortaya çıkarmak amacıyla logit modeller kurulmuş ve katsayılar tahmin edilmiştir. Tahmin sonuçları aşağıdaki tabloda verilmiştir. 
Tablo 11: Logit Model Tahmin Sonuçları

\begin{tabular}{|c|c|c|c|c|c|c|c|c|}
\hline \multicolumn{3}{|c|}{$\begin{array}{l}\text { Bağımlı Değiş̧ken: Genel } \\
\text { Seçim Kuklası }\end{array}$} & \multicolumn{3}{|c|}{$\begin{array}{l}\text { Bağımlı Değişken:Yerel } \\
\text { Seçim Kuklası }\end{array}$} & \multicolumn{3}{|c|}{$\begin{array}{l}\text { Bağımlı Değişken:Seçim } \\
\text { Kuklası }\end{array}$} \\
\hline Değişken & Katsayı & Prob & Değişken & Katsayı & Prob & Değişken & Katsayı & Prob \\
\hline $\begin{array}{l}\text { İşsizlik } \\
\text { oranı }\end{array}$ & -0.144 & 0.74 & $\begin{array}{l}\text { İssizlik } \\
\text { oranı }\end{array}$ & 0.41 & $\begin{array}{l}0.46 \\
4\end{array}$ & $\begin{array}{l}\text { İssizlik } \\
\text { oranı }\end{array}$ & -0.157 & 0.614 \\
\hline $\begin{array}{l}\text { TEFE'dek } \\
\text { i yüzde } \\
\text { artış } \\
\text { oranı }\end{array}$ & -0.038 & 0.91 & $\begin{array}{l}\text { TEFE'dek } \\
\text { i yüzde } \\
\text { artış } \\
\text { oranı }\end{array}$ & 0.003 & $\begin{array}{l}0.99 \\
1\end{array}$ & $\begin{array}{l}\text { TEFE'dek } \\
\text { i yüzde } \\
\text { artış } \\
\text { oranı }\end{array}$ & -0.121 & 0.645 \\
\hline $\begin{array}{l}\text { GSYH'da } \\
\text { ki yüzde } \\
\text { artış } \\
\text { oranı }\end{array}$ & 0.084 & 0.29 & $\begin{array}{l}\text { GSYH'da } \\
\text { ki yüzde } \\
\text { artış } \\
\text { oranı }\end{array}$ & -0.19 & 0.33 & $\begin{array}{l}\text { GSYH'da } \\
\text { ki yüzde } \\
\text { artış } \\
\text { oranı }\end{array}$ & 0.13 & 0.975 \\
\hline Sabit & -1.59 & $\begin{array}{l}0.73 \\
5\end{array}$ & Sabit & -8.964 & $\begin{array}{l}0.14 \\
3\end{array}$ & Sabit & -3.351 & $\begin{array}{l}0.000 \\
0\end{array}$ \\
\hline & $\begin{array}{l}\text { McFadde } \\
\mathrm{n} \mathrm{R}^{2}= \\
0.18\end{array}$ & & & $\begin{array}{l}\text { McFadde } \\
\mathrm{n} \mathrm{R}^{2}= \\
0.39\end{array}$ & & & $\begin{array}{l}\text { McFadde } \\
\mathrm{n} \mathrm{R}^{2}= \\
0.26\end{array}$ & \\
\hline
\end{tabular}

Tablo 11'den görüldüğü gibi, işsizlik oranındaki \%1'lik artış, genel seçim olma olasılığını \%14 azaltmaktadır. TEFE'deki yüzde \%1'lik artış, genel seçim olma olasılığını \%3 azaltmaktadır. GSYH'daki \%1'lik artış, genel seçim olma olasılığını \%8 artırmaktadır. Katsayılar istatistiksel bakımdan anlamsız bulunmuştur.

İşsizlik oranındaki \%1'lik artış, yerel seçim olma olasılığını \%41 artırmaktadır. TEFE' deki yüzde artış oranındaki \%1'lik artış, yerel seçim olma olasılığını binde 3 artırmaktadır. GSYH'daki \%1'lik artış, yerel seçim olma olasılığını \%19 azaltmaktadır. Katsayılar istatistiksel bakımdan anlamsız bulunmuştur. 
İşsizlik oranındaki \%1'lik artış, seçim olma olasılığını \%15 azaltmaktadır. TEFE'deki yüzde artış oranındaki \%1'lik artış, seçim olma olasılığını \%12 azaltmaktadır. GSYH'daki \%1'lik artış, seçim olma olasılığını \%13 artırmaktadır. Katsayılar istatistiksel bakımdan anlamsız bulunmuştur. 16 Nisan 2017 yılında yapılan referandumla, Cumhurbaşkanlığı Hükümet sistemine geçilmesinin GSYH, TEFE ve işsizlik sayısında bir değişiklik olup olmadığı da araştırılmak istenmiştir. 2017 ikinci çeyrek öncesi sonrası için (4.2), (4.3) ve (4.4) nolu modellerdeki katsayılar tahmin edilmiş ve tahmin sonuçları aşağıdaki tablolarda verilmiştir.

Tablo 12: GSYH Modeli Tahmin Sonuçları (Engle-Granger Yöntemi)

\begin{tabular}{|c|c|c|c|c|}
\hline \multicolumn{3}{|c|}{ 2002.4-2017.2 } & \multicolumn{2}{|c|}{ 2017.3-2020.04 } \\
\hline Değişkenler & Katsayı & Prob. & Katsayı & Prob. \\
\hline lyatirim & 0.333 & 0.0000 & 0.037 & 0.07 \\
\hline lkamu & 0.528 & 0.0000 & 0.885 & 0.0083 \\
\hline \multirow[t]{3}{*}{ Sabit } & 4.43 & 0.0000 & 5.11 & 0.0083 \\
\hline & $\begin{array}{l}\mathrm{ADF}_{\mathrm{U}}=-3.90 \\
\text { (p:0.01) }\end{array}$ & $\begin{array}{l}R^{2}=0.97 \\
F=947.70\end{array}$ & $\begin{array}{l}\mathrm{ADF}_{\mathrm{U}}=-3.81 \\
(\mathrm{p}: 0.02)\end{array}$ & $\begin{array}{l}R^{2}=0.94 \\
F=108.2\end{array}$ \\
\hline & & $F_{\text {chow }}=4.909$ & & \\
\hline
\end{tabular}

Tablo 12'den görüldüğü gibi Chow testi sonucunda iki dönemde katsayllar değişmiştir. Referandum öncesinde hem yatırım harcamalarının hem de kamu harcamalarının GSYH'yı artırdığı yani etkili olduğu görülürken; Referandum sonrasında, kamu harcamalarındaki artıştan kaynaklanan bir GSYH artışının olduğu görülmektedir. Yatırım harcamalarının GSYH üzerindeki etkisi azalmıştır.

Tablo 13:TEFE Modeli Tahmin Sonuçları (DEKK Yöntemi)

\begin{tabular}{|l|l|l|l|l|}
\hline 2002.4-2017.2 & \multicolumn{3}{|l|}{} & 2017.3-2020.04 \\
\hline Değişkenler & Katsayı & Prob. & Katsayı & Prob. \\
\hline lm2 & 0.05 & 0.086 & 0.51 & 0.018 \\
\hline ldolar & 0.08 & 0.0095 & 0.47 & 0.0026 \\
\hline lgsyh & 0.70 & 0.0000 & 0.73 & 0.014 \\
\hline Sabit & 5.29 & 0.000 & 13.35 & 0.095 \\
\hline & $\mathrm{R}^{2}=0.99$ & Fhow $_{\text {ch.127 }}$ & & $\mathbf{R}^{2}=0.99$ \\
\hline
\end{tabular}


Tablo 13'ten görüldüğü gibi Chow testi sonucunda iki dönemde katsay1lar değişmiştir. Referandum sonrasında hem döviz kurundaki hem de para arzındaki artışlar, referandum öncesine göre fiyatları daha fazla artırmıştır. Referandum sonrasında döviz kurundaki \%1'lik artış, fiyatları \%0.47 artırırken; referandum öncesi \%0.08 artırmaktadır. GSYH'daki artışların fiyatlar üzerindeki etkisi iki dönemde çok fazla değişmemiştir.

Tablo 14: İşsiz Sayısı Modeli Tahmin Sonuçları (DEKK Yöntemi)

\begin{tabular}{|l|l|l|l|l|}
\hline 2002.4-2017.2 & \multicolumn{3}{l|}{ 2017.3-2020.04 } \\
\hline Değişkenler & Katsayı & Prob. & Katsayı & Prob. \\
\hline ltefe & 1.87 & 0.0000 & 1.83 & 0.0000 \\
\hline lyatırım & -0.89 & 0.0000 & -0.52 & 0.0000 \\
\hline Sabit & 6.25 & 0.0000 & 9.54 & 0.0453 \\
\hline & $\mathrm{R}^{2}=0.85$ & Fchow $=3.49$ & & $\mathbf{R}^{2}=0.96$ \\
\hline
\end{tabular}

Tablo 14'ten görüldüğü gibi Chow testi sonucunda iki dönemde katsayılar değişmiştir. Referandum öncesi ve sonrasında fiyatlardaki artışın, işsiz sayısındaki artış üzerindeki etkisi birbirine benzerdir. Bununla birlikte Referandum öncesinde yatırım harcamalarındaki \%1'lik artış, işsiz sayısını \%0.89 azaltırken; referandum sonrasında \%0.52 azaltmaktadır.

\section{Sonuç}

Bu çalışmanın amac1, Türkiye'de 2002:04-2020.04 döneminde gerçekleştirilen genel seçimlerin, yerel seçimlerin ve hem genel hem de yerel seçimlerin bir arada alındiğ " seçimlerin", kamu tercihi teorisinde yer alan politik iş çevrimlerini yaratıp yaratmadığını ortaya koymaktır. $\mathrm{Bu}$ amaçla ihracat, Gayri Safi Yurtiçi Hasıla, Toptan Eşya Fiyat Endeksi, işsiz sayısı, takipteki kredilerin içsel değişken olarak alındığı 5 ayrı eşanlı model kurulmuştur. Eşanlı modellerde yer alan değişkenlere ADF testi uygulanmış ve tüm değişkenler birinci sıra fark durağan bulunmuştur. Ayrıca kurulan eşanlı modellerin üçünde içsellik sorunu vardır. Bu yüzden üç modele hem içsellik sorununa çözüm getiren hem de durağan olmayan değişskenler arasında bir eşbütünleşme ilişkisini 
araştıran yöntemlerden biri olan Dinamik EKK yöntemi kullanılmıştır. Diğer iki modele de EngleGranger yöntemi uygulanmıştır.

Tahmin sonuçları genel olarak değerlendirildiğinde, kukla değişkenler eklenmeden katsayıları tahmin edilen modeller ele alındığında;

- İşsiz sayısında ve fiyatlar genel düzeyindeki artışlar, takipteki kredileri artırmaktadır.

- Para arzı ve döviz kurundaki artışlar, fiyatlar genel düzeyini artırmaktadır.

- Yatırım harcamalarındaki artışlar hem ihracatı hem de geliri(GSYH)artıııken; işsiz sayısını ve takipteki kredileri azaltmaktadır.

Kukla değiş̧kenler eklenerek, katsayıları tahmin edilen modeller ele alındığında;

- Genel seçimlerde ve "seçimlerde", ihracat azalma eğiliminde, yerel seçimlerde ihracat artma eğilimindedir. Kukla değişkenlere ait katsayılar anlamlı bulunduğu için seçimlerin ihracat üzerinde politik iş çevrimi yarattığı söylenebilir.

- Tüm seçimlerde takipteki krediler azalma eğilimindedir ve fiyatlar genel düzeyi artma eğilimindedir. Tüm seçimlerin takipteki krediler ve fiyatlar genel düzeyi üzerinde politik iş çevrimi yaratmadığı söylenebilir.

- Genel seçimlerde işsiz sayısı azalma eğiliminde, ancak yerel ve "seçimlerde" işsiz sayısı artma eğilimindedir. Tüm seçimlerin işsiz sayısı üzerinde politik iş çevrimi yaratmadığı söylenebilir.

- Genel seçimlerde gelir(GSYH) azalma eğiliminde, yerel seçimlerde ve "seçimlerde" gelir artma eğilimindedir. Tüm seçimlerin GSYH üzerinde politik iş çevrimi yaratmadığı söylenebilir.

Logit modellerden elde edilen sonuçlar ele alındığında, "seçimlerde" işsizlik oranındaki \%1'lik artış, seçim olma olasılığını \%15 azaltmaktadır. TEFE'deki yüzde artış oranındaki \%1'lik artış, seçim olma olasılığını \%12 azaltmaktadır. GSYH'daki \%1'lik artış, seçim olma olasılığını \%13 artırmaktadır. Hükümetin tercihi ekonomik büyüme ise yüksek bir büyüme oranı olduğunda seçim yapılabilir. 
Ayrıca 16 Nisan 2017 yılında yapılan referandumla, Cumhurbaşkanlığı Hükümet sistemine geçilmesinin gelir, fiyatlar genel düzeyi ve işsizlik sayısında bir değişikliğe neden olup olmadığ araştırılmak istenmiştir. Chow testi sonuçlarına göre iki dönem için de katsayılar da değişiklik olmuştur. Referandum öncesinde hem yatırım harcamalarının hem de kamu harcamalarının geliri artırdığı yani etkili olduğu görülürken; referandum sonrasında, kamu harcamalarındaki artıştan kaynaklanan bir GSYH artışının olduğu görülmektedir. Yatırım harcamalarının GSYH üzerindeki etkisi azalmıştır. Referandum sonrasında hem döviz kurundaki hem de para arzındaki artışlar, referandum öncesine göre fiyatları daha fazla artırmıştır.

Sonuç olarak, seçim dönemlerini tanımlayan kukla değişkenlere ait anlamlı katsayılara ulaşılamamasının açıklaması, seçimlerden önce alınan manipülatif kararların ve ayarlamaların her zaman iş çevrimi yaratmayabileceğidir. Çünkü kimi zaman seçim dönemlerinde yapılan harcamalar sisteme kalıcı bir yük haline gelir ve bu yüzden seçim dönemlerindeki ekonomik ayarlamalar politik iş çevrimleri kapsamında anlamlı sonuçlar üretmeyebilir (Balyemez, 2018: 172). Ayrıca iktidarın politika amaçlarını manipüle etmeleri, politika araçlarını manipüle etmelerine göre daha zordur. Çünkü kamu harcamaları, para arzı gibi politika araçları büyük oranda iktidarın kontrol alanında iken Gayri Safi Yurtiçi Hasıla, enflasyon ve işsizlik gibi göstergelere iktidar müdahalesi sınırlıdır. $\mathrm{Bu}$ yüzden bu politika amaçlarında politik iş çevrimlerinin görülmemesi şaşırtıcı değildir (Alesina vd., 1991; Eryılmaz, 2014: 210).

\section{Kaynakça}

Akçoraoğlu, A. ve Yurdakul, F. (2004). Siyasal Ekonomi Açısından Büyüme, Enflasyon ve Bütçe Açıkları: Türkiye Üzerine Bir Uygulama. Ankara Üniversitesi SBF Dergisi, 59(1), 1-25.

Alesina, A. ve Cukierman, A. (1990). The Politics of Ambiguity. Quarterly Journal of Economics, 105(4), 829-850.

Alesina, A., Cohen, G.D. ve Roubini, N. (1991). Macroeconomic Policy and Elections in OECD Democracies. Economics \& Politics, 4(1), 1-30.

Al-Athwari, B. (2019). Yemen Ekonomisinde İşsizliği Etkileyen Faktörler: Ekonometrik Bir Analiz, Yüksek Lisans Tezi, Selçuk Üniversitesi, SBE, Konya.

Altıok, M. (2016). Politik Konjonktür Dalgalanmaları Teorisi Türkiye Uygulaması (1980-2015), Yüksek Lisans Tezi, Bülent Ecevit Üniversitesi, SBE, Zonguldak. 
Altun, T. (2014). Türkiye'de Fırsatçı ve Partizan Politik Konjonktürel Dalgalanmalar: 1950-2010. Marmara Üniversitesi İBF Dergisi, 36(2), 47-69.

Altunç, Ö. F. (2011). Kamu Harcamaları ve Ekonomik Büyüme İlişkisi: Türkiye'ye İlişkin Ampirik Kanttlar. Yönetim ve Ekonomi, 18(2),145-157.

Balyemez, A. S. (2018). Seçimlerin Kamu Maliyesi Üzerindeki Etkileri ve 2018 Seçimleri. Manisa Celal Bayar Üniversitesi Sosyal Bilimler Dergisi, 16 (4), 161-196.

Bozkurt, H. (2010). Eğitim, Sağlık ve İktisadi Büyüme Arasındaki İlişkiler: Türkiye İçin Bir Analiz. The Journal of Knowledge Economy \& Knowledge Management, 5(1), 7-27.

Efthyvoulou, G. (2012). Political Budget Cycles in the European Union and the Impact of Political Pressures. Public Choice, 153, 295-327.

Ekelund, R. B. ve Tollison, R. D. (1986). Instructor's Resource Materials for use with Economics. Boston: Little, Brown.

Engle, R.F. ve Granger, C.W. (1987). Cointegration and Error Correction: Representation, Estimation and Testing. The Econometric Society, 55, 251-276.

Erdoğan, S. ve Bozkurt, H. (2009). Demokratik Rejimlerde Politik Parasal Konjonktür Hareketleri: Türkiye Üzerine Ekonometrik Bir İnceleme. Doğuş Üniversitesi Dergisi, 10(2), 204-216.

Eryılmaz, F. (2014). Politik Konjonktür Teorileri Işı̆̆ında Türk İktisat Politika Çıktılarının Analizi. Doktora Tezi, Uludağ Üniversitesi, SBE, Bursa.

Gökdemir, S. (2016). Politik Konjonktür Dalgaları ve Geleneksel Fırsatçı Modelin Türkiye’ye Uygulanması (1950-2013). Doktora Tezi, Karadeniz Teknik Üniversitesi, SBE, Trabzon.

Güdenoğlu, E. (2018). Türkiye'de Politik Konjonktür Dalgalanmalarının Analizi. Doktora Tezi, Bülent Ecevit Üniversitesi, SBE, Zonguldak.

Jackman, M. ve Lorde, T. (2010). On the Relationship between Tourist Flows and Household Expenditure in Barbados: A Dynamic OLS Approach. Economics Bulletin, 30(1), 472-481.

Kahveci, M. ve Pelek, S. (2021). Asgari Ücret ve Politika: Asgari Ücreti Seçimler mi Belirliyor? Amme İdaresi Dergisi, 54(1), 99-131.

Kaplan, S. B. (2008). Do Elections Hurt Developing Economies? https://papers.ssrn.com/sol3/papers.cfm?abstract_id=1121488. Erişim Tarihi: 13.07.2021.

Karaca, O. (2003). Türkiye'de Enflasyon - Büyüme İlişkisi : Zaman Serisi Analizi. Doğuş Üniversitesi Dergisi, 4(2), 247-255.

Karagöl, E. T. ve Turhan, A. (2008). External Debt, Defence Expenditures and Political Business Cycles in Turkey. Defence and Peace Economics, 19(3), 217-224.

Klose, J. (2011). Political Business Cycles and Monetary Policy Revisited - An Application of a Two-Dimensional Asymmetric Taylor Reaction Function. International Economics and Economic Policy, 9(3), 1-37. 
Lindbeck, A. (1976). Stabilization Policy in Open Economies with Endogenous Politicians. American Economic Association, 66(2), 1-19.

Mushtaq, R. (2011). Augmented Dickey Fuller Test. SSRN: https://ssrn.com/abstract=1911068 or http://dx.doi.org/10.2139/ssrn.1911068. Erişim Tarihi: 8.06.2021.

Özciğer, A. (2020). Makroekonomik Göstergelerin Takipteki Kredilere Etkisi: Türkiye'de Sektörel Bazlı bir Uygulama, Yüksek Lisans Tezi, İstanbul Üniversitesi, SBE, İstanbul.

Özkan, F. ve Tarı, R. (2010). Türkiye'de 1980 Sonrası Seçim Dönemlerinin Politik Konjonktürel Dalgalanmaları Teorisi Çerçevesinde Analizi. Erciyes Üniversitesi İktisadi ve İdari Bilimler Fakültesi Dergisi, 36, 223 - 238.

Parlaktuna, İ. ve Bahçe, A. B. (2006). Politik Konjonktür Dalgalanmalarının Ekonomi Üzerindeki Etkisi ve Türkiye Uygulaması (1980-2006). Eskişehir Orhangazi Üniversitesi Sosyal Bilimler Dergisi, 7(2), 1-19.

Sert, O. (2009). Seçimlerin Türkiye Üzerinde Yarattığı Etkiler: Hendry Yaklaşımı, Yüksek Lisans Tezi, Gazi Üniversitesi, SBE, Ankara.

Sezgin, Ş. (2005). Türkiye'deki Politik Konjonktürel Dalgalanmalar: 1950-2003 Dönemi. Ankara Üniversitesi SBF Dergisi. 62(2), 136-154.

Stock, J. H. ve Watson, M. W. (1993). A Simple Estimator of Cointegrating Vectors in Higher Order Integrated Systems. Econometrica, 61, 783-820.

Tayyar, A. E. (2020). Türkiye'de İçsel Seçim Teorilerinin Geçerliliği: Müdahale Analizi Uygulamas1. Finans-Politik \& Ekonomik Yorumlar Dergisi, 57(651), 59-80.

Yalta, T. ve Yalta Y. (2019). Modern Makro Ekonomiye Giriş. Ankara. Liberta Yayın Grubu.

Y1lmaz, K. R., ve Y1lmaz, D. Ö. (2018). Türkiye'de Bölgesel Ekonomik Hoşnutsuzluk Endeksi ve Yerel Seçimler: Politik Makroiktisat Bağlamında Bir Analiz. Emek Araştırma Dergisi, $3(2), 65-84$

Yurdakul, F. (2018). Kişi Başına Enerji Tüketimi ile Büyüme Oranı Arasındaki İlişki: Türkiye Örneği. Ekonomik Yaklaşım, 29(107), 49-76.

Zivot, E. ve Andrews, D. W. (1992). Further Evidence on the Great Crash, the Oil-Price Shock, and the Unit-Root Hypothesis. Journal of Business \& Economic Statistics, 10(3), 251-270. 